\title{
Assessing the Financial Soundness of Indian Aviation Sector Companies by Using Altman's Z-Score Model \& Pilarski's P- Score Model
}

\author{
Vivek Divekar*, Sreerupa Sukhari \\ Symbiosis Institute of Management Studies, Symbiosis International (Deemed University), Pune, Maharashtra, India
}

Received May 12, 2021; Revised June 19, 2021; Accepted June 30, 2021

\section{Cite This Paper in the following Citation Styles}

(a): [1] Vivek Divekar, Sreerupa Sukhari, "Assessing the Financial Soundness of Indian Aviation Sector Companies by Using Altman's Z-Score Model \& Pilarski's P-Score Model," Universal Journal of Accounting and Finance, Vol. 9, No. 6, pp. 1222 - 1234, 2021. DOI: 10.13189/ujaf.2021.090602.

(b): Vivek Divekar, Sreerupa Sukhari (2021). Assessing the Financial Soundness of Indian Aviation Sector Companies by Using Altman's Z-Score Model \& Pilarski's P-Score Model. Universal Journal of Accounting and Finance, 9(6), 1222 - 1234. DOI: 10.13189/ujaf.2021.090602.

Copyright $\odot 2021$ by authors, all rights reserved. Authors agree that this article remains permanently open access under the terms of the Creative Commons Attribution License 4.0 International License

\begin{abstract}
The COVID 19 has brought down aviation industry to its knees. Till March 2020, before getting sense of distraction by this pandemic, Indian economy was eager to take off to reach further heights including the Aviation Sector. The growing middle class was the base reason for the prosperity in the Aviation Sector, but the pandemic has changed the whole scenario at least temporarily for next couple of years. However, even before the pandemic the history is showing that almost all Indian airlines companies are in losses. Jet Airways is almost grounded permanently whereas Kingfisher Airlines is now a history. Being one of the important sectors for the economy and even for the investors, an attempt is made to find out the reasons behind financial failure of selected Indian Aviation Companies by using Altaman's Z Score Model and Pilarski's P -Score Model and various problems faced by them. The secondary data is collected mainly by using Annual Reports of 4 leading Airlines Companies in India. Analysis is showing that various internal and external factors which are responsible for such pathetic financial position of these companies and a serious overhauling is required not only by those companies but also from the government side.
\end{abstract}

Keywords Financial Distress, Financial Analysis, Discriminate Analysis, Bankruptcy, Z-Score, Financial Ratios

\section{Introduction}

Every Company faces the problem of liquidity or operating efficiency in its life. However, when a company is landing into financial distress it directly impacts on the value of the company's business. There are different reasons for a company going into financial distress and defaults in payment of external obligations and it's a very embarrassing position to all the stakeholders. There are number of reasons for this situation right from incompetence of the management to the bad capital structure [1]. Company is not able to generate sufficient EBITDA to service its interest payment and principle loan amount. It is a very common situation where funds required for the growth are funded by external parties, however, gradually company is either losing its top line to the competitors or management is not efficient enough to keep the operating costs under control which is pressurizing EBITDA and Operating margins and ultimately ends with default in making payment to lenders and other external parties. Other important area for such situation is wrong planning about investment in Fixed Assets. Excess investment in fixed assets is directly impacting on asset efficiency which in turn again pressurizes top line and ultimately cash flow generation. Wrong product mix, poor emphasis on product research and development, no quality control, poor sales promotion, inadequate human resources, exchange fluctuation and so 
on so forth, Recently we have seen number Corporate Groups are on the verge of collapse because of COVID 19 impact on their business including Aviation sector [2].

There was a news buzz in the market that Indian Aviation business has reached to its bottom and Airlines Companies in India are expecting a relieving package for their survival. Number of flights per day has gone down almost to 700 to 800 per day from 3,300 to 3,400 per day. Load factors have dropped to 40 to $45 \%$ from $85 \%$ to $90 \%$ before the pandemic. Total number of passengers travelling has gone down to two million from twelve million before lockdown. This position is understandable because this scenario is in all airlines all over the world. In India even before the pandemic, situation was not very encouraging. Government of India has kept Air India for sale for last two years with no success because of poor financial condition of Air India. At the same time corporate group Tata has shown interest in buying Air India even though they are already controlling two Airlines Companies, Air Asia and Vistara in India. This situation tempted us to study the real reasons and to find out financial distress of number of Airlines Companies in India. With this background, an attempt is made to study aviation sector in India to find out various reasons for the business failures and while analyzing financial distress of Aviation Sectors in India a deliberate attempt is made to find out the financial distress position before $31^{\text {st }}$ March, 2020 when the impact of COVID 19 was not that visible at least in the domestic business.

Airline Industry in India is having its own problems. This industry is growing very fast in India, particularly in last 10 years. However, during the same period we have seen failure of two market leaders Kingfisher Airlines and Jet Airways. There are different reasons for failure for both, but there are few reasons common in nature. Remaining five players in the market are trying their best for their survival and growth. All are different with their market share, Capital structure, business model, age, control. The industry is under the control of DGCA (Directorate General of Civil Aviation), companies which are listed are further governed by Securities \& Exchange Board of India and different listing requirements and provisions of the Companies Act, 2013. Major external issues for the industry are the aircraft fuel prices in which they cannot do much, Different agreements for leasing of Aircrafts and agreements for repairs and maintenance of the aircrafts. Object of this research is to find out various reasons for the financial distress of these Companies and to point out major issues associated to the Aviation Sector [3] particularly areas which are not covered earlier Research Papers such as to find out whether the LCC model which is dominating Indian aviation sector is the main cause failure or limitations on the part of the companies to keep their fixed costs under control for example Lease model instead of Buy model for aircrafts where a fixed lease rent payment is coming into the picture which pressurizes working capital requirements of the company and its profitability.

The Paper is divided in following parts

1. Introduction to Aviation Sector in India

2. Literature Review

3. Research Methodology

4. Financial discussion by using $\mathrm{Z}$ score Model \& Pilarski P Score Model

5. Conclusion

6. References

\section{Literature Reviews}

Presently, the Indian Aviation sector off lately appears not to be as shaped as it should be. However, there has been a not a constant growth in Aviation sector, an in-depth study would reflect the darker side. The situation is already disappointing with the falling performance of large players and the exit of Kingfisher Airlines, being bankrupt. There are number of research papers on Aviation sector in India by using Z score model.

The earliest studies were conducted by Beaver, W.H. (1966) where an empirical study of a biased sample was investigated for the usefulness of ratios. Inferences drawn from his studies concluded that ratio analysis can be very instrumental in prediction of failure for at least 5 years before failure [4]. In the Indian context, An empirical study analysing the financial distress of the Navratna Companies of India was made by Rajasekar et.al,(2004). Their research suggested that even though these organizations were funded by Government and thus, there lies a very low chance of bankruptcy, caused by financial distress still they should check their financial status frequently, in order to avoid financial crisis and sustain in the market with credible reputation.

Later in the year 2012, Bhatt, S.N. (2012) investigated the capability of three versions of Altman's Z-Score and the results of the study shows that a remarkable degree of accuracy by these models, in prediction of the financial distress with use of financial ratios computed for the year prior to distress. Anjum, S.(2012) research work tried to summarize Altman's research of development of the Altman's Z Score model. The researcher studied the repeated regular changes made by Altman for achieving the perfect equation that could predict the bankruptcy. It was concluded that $\mathrm{Z}$ Score model is reliable for application in modern economies for prediction of distress and bankruptcy, two to three years in advance [5].

In 2013, Pandey et.al., analyzed the bankruptcy of Indian aviation companies through prediction models like Z-score and Air-score models. They implicated its use for the stakeholders to avoid recurring losses and help company to head in better directions.

With reference to logistic companies like GATI Ltd, Aegis, Container Corporation, another study was conducted, analyzing the financial health of logistics 
sector for the period of 2005-06 to 2011-12 by Tyagi, V.(2014). He concluded that at the time of being hit by Global recession, the average $\mathrm{Z}$ score value of the selected firms experienced an increasing scale. He extended his research work in 2017 with another research publication.Attempts were also made to check the financial risk of companies using Z-scores in other sectors. Gowri et.al., (2014) attempted to study about the financial health of the automobile companies in India for a period of 10 years from FY 2003-04 TO 2011-12, using Altman's Z-scores. Since, the research on the same was very limited in India, the paper focussed to apply and interpret the financial performance of automobile industry using Z-scores. Bankruptcy models have always been very common tool for financial analysis and prediction of financial distress of companies. Machek, O. (2014) analysed the ex-ante predictive ability of a few selected solvency and bankruptcy models, which are commonly used for analysing the finances. He considered the Czech companies over the span of 5 years (2007-2012) for his research work [6].

Pradhan, R.(2014) emphasizes the usage of BPNN for predicting bankruptcy in public sector banks in India. His research work provides the $\mathrm{Z}$ score values for the public sector banks. It was concluded that, these values were proved to be very useful when these banks demand for loans from funding agencies or RBI.

Since the Central Public Sector Enterprises (CPSEs) are regarded as one of the instrumental factors causing socio-economic transformation of the country, Pardeshi et, al (2015) tried analysing the financial performance and efficiency of selected Central Public Sector Enterprises (CPSEs) an evaluated the financial health suing the Altman's Z Score. It was concluded that, SAIL and NTPC were in distress zone. However, BEL. ONGC and RCF were at medium level of solvency.

After few years, in 2017, Tyagi et. al., attempted to compare the results of the then present financial situation over a period of (2010-2014) with the pre-bankruptcy period (2008-2012) of Kingfisher Airline.

In the same year, Kolte et.al., (2017) aimed at studying the reasons of bankruptcy and checked the possibility for banks to assess the creditworthiness and if banks could have abstained from lending credits to Kingfisher Airlines. They made their conclusions on the basis of results of $\mathrm{Z}$ Scores. Parallel to Kolte's study, Safiuddin, S.K. (2017) attempted to analyse the possibility of insolvency of selected Airline Companies. To the Indian Context, two aviation companies were selected for calculation of $\mathrm{Z}$ Scores. In this attempt he again considered the period of 10 years(2007-2016). Conclusions were drawn from the study that states that Indigo had performed well in financial ratios and Z-Scores. On the contrary was the performance of Jet Airways, which was predicted to be in distress in the coming two years, if corrective actions have not been take [7].
Kulkarni. S.(2018) used the Altman's Z Score model for prediction of Bankruptcy in the same sector and considered 6 listed companies like TAAL Enterprises, Jagson Airlines, Global Vectrs Helicorp, Jet Airways, Spice Jet, Indigo Airways and Air India for his research study. He concluded the safety of Indigo Airlines backed by calculation of it's Z-Score to be 2.9, back in 2018, whereas according to his study, all the other companies were in financial distress.

Safiuddin, S.K. (2019) attempted to study the impact of Profitability, liquidity and efficiency performance on Z score of selected Aviation companies of India, leveraging the use of $\mathrm{Z}$ score model and the needed financial ratios. He considered a time span of 10 years (2007-2016).

A recent study was done accessing the financial health of different Indian Airline companies using different calculated models like Fuzzy Logic Model Altman Modified Z" Score Model, Pilarski Model etc., by Shome et.al. (2020). They targeted to assess the current financial health of different airline companies of India and concluded the suitability of studied models that helps in indicating the financial distress leading to potential bankruptcy [8].

Wang et. Al., (2010) attempted to consider publicly listed companies of China to provide ex ante evidences of failure of prediction power of the Z-Score model. The results showed that Altman's (1968) Z-Score model has the least accuracy of prediction, while the revised model had better results. It also confirms that the existing Z-Score models have been very useful for the prediction of company delistings.

Gritta et.al., (2011) used the Z-score model for providing an update on financial health of the major U.S. air carriers. They concluded that the major factor in the decline of financial health was the combination of decreased equity values and increased use of debt. They summarized that if the industries majorly rely on the debt, it could have negative impact on the major carriers, provided the interest rates rise again in coming years.

Anindya Ardiansari, Siti Ridloah, Irene Rini Demi Pangestuti and Pipit Indrayani [19] in their paper on The Influence of Intellectual Capital on the Company's Financial Performance and Market Value aiming to find out the relation between increase in intellectual capital on financial performance of a company and its market value.

\section{Sample, Data and Methodology}

Through this study, attempt is made to find out the financial distress of Indian Aviation sector and reasons behind it by selecting major Four Aviation companies India as Indigo, Spicejet, Jet Airways and Air India. Jet Airways even though grounded at present is taken into consideration because of the past performance of this company. Data are taken from Annual Report of all these 
Companies and from the website of DGCA. Financial data considered for four years i.e., 2015-16, 2016-2017, 2017-2018 and 2018 - 2019. Financial data for the year 2019-2020 not considered because of non-availability of financial data of all the companies for the year 2019-2020 and introduction of Ind as 116 from $1^{\text {st }}$ April, 2019 has changed the presentation of leased assets in the Balance Sheet which is not comparable with previous year's data [9].

\subsection{Methodology}

The financial data taken for four years on consolidated basis from the Annual Reports of these Companies to apply Altman's Z score and Pilarski's P- Score used to check the financial distress and bankruptcy position.

\subsection{Evaluating Financial Distress}

There are different parameters to find out financial distress. In fact, when a Company is in financial distress it is going to make default to its creditors either financial or operational in near future, When a company is in financial distress companies survival is in difficult stage. Delayed payment to suppliers, overdrawing credit limits, default in payment of instalments to the bank, default in payment of statutory dues, erosion in the valuation of shares, employees are leaving the organization, declining capacity utilization, declining market reputation.

There are various reasons also internal as well as external for a company to be under financial distress such as managerial incompetency, over investment in fixed assets, irrational price structure, poor customer service, poor demand projections etc. Similarly external factors such as Government policies, entry of larger number of competitors etc. To find out such situation, number of ratios can be calculated such as Interest coverage ratio, Debt Service Coverage Ratio, Debt Equity Ratio, Short Term Debt to Current Assets, and Short Term Debt to Cash from Operations and so on. Experts worked on this issue in the past to find out the early signs of corporate distress so as to take appropriate action. $\mathrm{P}$ - Score Model was used to find out financial distress of Aviation sector in the past. In US a Neural Network Model was used to check financial distress in small airlines companies. In 2002, a logistic regression model was used successfully to find out financial distress. In our study we have used Altaman's Z score model which is touching upon five important financial areas to find out financial distress and also Pilarski P Score model which focuses on different five financial ratios which are indicating bankruptcy position of the business.

Number of papers is high lighting on the financial factors which are indicating financial distress of the business and early indicative signs. In this paper we are focusing along with financial factors other managerial factors which are important reasons to bring those companies into financial distress. For example in case of Jet Airways, management failed to foresee the impact on their business because of the entry of LCC model used by Indigo whereas Air India management never attempted to reduce the fixed cost. Almost every airline was not focusing at all on cargo business as additional source to generate cash inflows.

\subsection{Altman Z-Score Model}

Altman's Z-score model is one of the best models to assess the financial soundness of any firm and is globally accepted in the field of management. This model developed by Altman is a great method for credit risk investigation [10].

At first, the investigation had picked 22 factors or correlations from issued financial reports of 66 firms in the USA for assessment dependent on the prevalence in the writing and pertinence to the examination. At that point arranged into five standard proportion classifications: liquidity, activity, leverage, solvency, and profitability, After a unique rundown of 22 factors, five were selected based on numerous models that incorporate their factual essentialness, relative commitment to the model, interrelations among variables, their insightful precision, and the judgment of the investigator. The final result of that study is mentioned below: The Final Result of $\mathrm{Z}$ Score guide is Equation 1.

$$
\mathrm{Z}-\mathrm{Score}=1.2 *\left(\mathrm{Z}_{1}\right)+1.4 *\left(\mathrm{Z}_{2}\right)+3.3 *\left(\mathrm{Z}_{3}\right)+0.6 *\left(\mathrm{Z}_{4}\right)+1.0 *\left(\mathrm{Z}_{5}\right)
$$

Table 1. Z-Score Guide

\begin{tabular}{|c|c|}
\hline \multicolumn{2}{|c|}{ Z-Score Guide } \\
\hline Z1 & (Net Working Capital/ Total Assets)*1.2 \\
\hline Z2 & (R\&S/Total Assets)*1.4 \\
\hline Z3 & (EBIT/Total Assets)*3.3 \\
\hline Z4 & (Market Capitalization/Outside Liability)*0.6 $^{*}$ (Sales/ Total Assets)*1 \\
\hline Z5
\end{tabular}

Where $Z_{1}, Z_{2}, Z_{3}, Z_{4}, Z_{5}$ represents five ratios as given below:

$\mathrm{Z}_{1}$ is equal to Working capital/Total assets

$\mathrm{Z}_{2}$ is equal to Retained earnings/Total assets

$\mathrm{Z}_{3}$ is equal to EBIT/Total assets

$\mathrm{Z}_{4}$ is equal to Market value of equity/Total liabilities

$Z_{5}$ is equal to Net sales/ Total assets

After completing his study Altman (1968) interpreted the results of $\mathrm{Z}$ score as shown below:

$\mathrm{Z}<1.8$ Very high probability of insolvency (Risky Zone);

$1.8<\mathrm{Z}<3$ Very Poor financial health and risks of insolvency are high (Grey Zone);

$\mathrm{Z}>3$ Strong financial position with negligible risks of insolvency (Safe Zone); 
P - Score Model - P Score model is also based on five different ratios with different weightages

1. Operating Revenue/Total Assets,

2. Retained Earnings/Total Assets

3. Equity/Total Debts

4. Liquid Assets/Current Obligation of total debt

5. Operating Profit/Sales

$\mathrm{P}$ means probability of bankruptcy. Higher the score more the possibility of bankruptcy, the weights are

$$
-1.98 \mathrm{X} 1-4.95 \mathrm{X} 2-1.96 \mathrm{X} 3-0.14 \mathrm{X} 4-2.38 \mathrm{X} 5
$$

Then the number $\mathrm{P}$ is determined by $\mathrm{P}=1 /(1+\mathrm{e})$. Here value of "E" can be taken approximately 2.718 . The weight of $\mathrm{P}$ value is measured through the Equation 2.

Table 2. Aviation Business in India data collected from DGCA website

\begin{tabular}{|c|c|c|c|c|}
\hline Year & $\begin{array}{c}\text { Domestic } \\
\text { Passengers } \\
\text { (In millions) }\end{array}$ & $\begin{array}{c}\text { Growth } \\
\text { in \% }\end{array}$ & $\begin{array}{c}\text { International } \\
\text { Passengers } \\
\text { (In millions ) }\end{array}$ & $\begin{array}{c}\text { Growth } \\
\text { in \% }\end{array}$ \\
\hline $2015-16$ & 85.20 & $21.58 \%$ & 49.78 & $8.85 \%$ \\
\hline $2016-17$ & 103.75 & $21.77 \%$ & 54.68 & $9.84 \%$ \\
\hline $2017-18$ & 123.32 & $18.86 \%$ & 60.58 & $10.79 \%$ \\
\hline $2018-19$ & 140.33 & $13.79 \%$ & 63.88 & $5.43 \%$ \\
\hline
\end{tabular}

International Passengers includes Departing as well as Arriving Passengers

Table 3. Market share of top 4 Indian Airlines Companies in Percentage

\begin{tabular}{|c|c|c|c|c|}
\hline Name of Company & $\mathbf{2 0 1 5 - 1 6}$ & $\mathbf{2 0 1 6 - 1 7}$ & $\mathbf{2 0 1 7 - 1 8}$ & $\mathbf{2 0 1 8 - 1 9}$ \\
\hline Indigo & 36.90 & 40.10 & 39.70 & 43.00 \\
\hline Spice jet & 12.50 & 12.80 & 13.10 & 13.00 \\
\hline Jet Airways & 21.60 & 18.40 & 17.20 & 14.00 \\
\hline Air India & 15.20 & 13.86 & 12.10 & 11.10 \\
\hline Others & 13.80 & 14.84 & 17.90 & 18.90 \\
\hline
\end{tabular}

Table 4. Number of Aircraft held by Indian Airlines Companies

\begin{tabular}{|c|c|c|c|c|}
\hline No. of Aircrafts & $\mathbf{2 0 1 5 - 1 6}$ & $\mathbf{2 0 1 6 - 1 7}$ & $\mathbf{2 0 1 7 - 1 8}$ & $\mathbf{2 0 1 8 - 1 9}$ \\
\hline Indigo & 107 & 131 & 163 & 217 \\
\hline Spice jet & 34 & 49 & 62 & 111 \\
\hline Jet Airways & 116 & 115 & 113 & 118 \\
\hline Air India & 118 & 126 & 159 & 151 \\
\hline
\end{tabular}

Table 5. Number of Passengers in Domestic Market

\begin{tabular}{|c|c|c|c|c|}
\hline $\begin{array}{c}\text { No. of } \\
\text { Passengers }\end{array}$ & $\mathbf{2 0 1 5 - 1 6}$ & $\mathbf{2 0 1 6 - 1 7}$ & $\mathbf{2 0 1 7 - 1 8}$ & $\mathbf{2 0 1 8 - 1 9}$ \\
\hline Indigo & 31453451 & 41600088 & 48955983 & 48955983 \\
\hline Spice jet & 10670866 & 13236143 & 16130815 & 17655832 \\
\hline Jet Airways & 18401029 & 19027140 & 21308273 & 19397067 \\
\hline Air India & 12891380 & 13845073 & 14886170 & 15673411 \\
\hline
\end{tabular}

\section{For Jet Air ways data for Jet lite added and similarly for Air India, data for Air India Express added}

Table 2 is indicating that number of passengers on year-on-year basis is going up even though the growth rate is going down both for domestic as well as for international business. Table 2 is indicating the Aviation Business in India data collected from DGCA website. Market share of indigo is around $40 \%$ and has gone up considerably in the year 2018-2019 because of fall down of Jet Airways. Jet Airways has started losing ground gradually and started losing market share year on year basis. Table 3 is indicating the Market share of top 4 Indian Airlines Companies in Percentage. However important point to note that even the year in which Jet Airways grounded, their market share is slightly better than Spice Jet. Table 4 is indicating Number of Aircraft held by Indian Airlines Companies. Naturally question arises suddenly what happened that jet Airways had to close down its business and they were not able to Air craft fuel charges and even salary to their employees. Also, others include Go Air, Vistara, Air Asia who are trying to increase their presence in the market however so far Indigo is dominating the market. Table 5 is indicating the Number of Passengers in Domestic Market [11].

If we observe number of Aircrafts, Indigo has increased its fleet year on year basis, Spice jet has also increased particularly in the year 2018-19 whereas Jet Airways and Air India are almost having the same number for two years. Out of total number of aircrafts, Jet Airways owns only three Aircrafts whereas all remaining are taken on Operating Lease basis and few on Financial Lease basis.

\subsection{Data Analysis and Interpretation}

\section{Sample Companies:}

$\mathbf{Z}_{1}$ : A higher value of $Z_{1}$ indicates liquidity position of the company. It compares Net Working Capital with Total Assets. For any organization, combination of fixed assets and Working Capital is very important. Out of total assets how much amount is invested in Fixed Assets and how much is invested in Working Capital becomes very vital. For Airlines business where aircraft fuel expenses, repairs and maintenance of aircrafts and salary are day to day expenses where lot of ready cash is required so if company is having sufficient Net Working Capital, it is a very good sign. If we check at present Indigo is the only Company which can be survived in the pandemic situation because of sufficient bank balance and capacity to raise funds at any point of time. [12]

Table 6. Sample Selected from Indian Aviation Sector

\begin{tabular}{|c|}
\hline Company \\
\hline Indigo \\
\hline SpiceJet \\
\hline Jet Airways \\
\hline Air India \\
\hline
\end{tabular}


$\mathbf{Z}_{2}$ : It talks about retained earnings to Total Assets. It indicates relation between these two and in short talks about past performance of the Company. Accumulated profits which are building the Reserves \& Surplus of the Company and which ultimately created Total Assets of the business. From the table we can say that

$\mathbf{Z}_{3}$ : Operating Profit is the key for any business. It indicates how efficiently management is running the business to maximize profit generated from main business activity. It also indicates overall Operating margins business can generate which depends on nature of its business. It also focuses on investment in Total Assets to generate operating profits. Altaman has given maximum weightage to this ratio. From the Table 7 we can say that:

$\mathbf{Z}_{4}$ : This ratio talks about comparison of Market Capitalization and outside liabilities. It indicates value created for Companies shares through market capitalization and total amount contributed by outsiders in the business. From the Table we can say that

Z5: This ratio focuses on utilization of total Assets to generate maximum sales, which includes utilization of Tangible Fixed Assets, Intangible Fixed Assets as well as utilization of Current Assets.
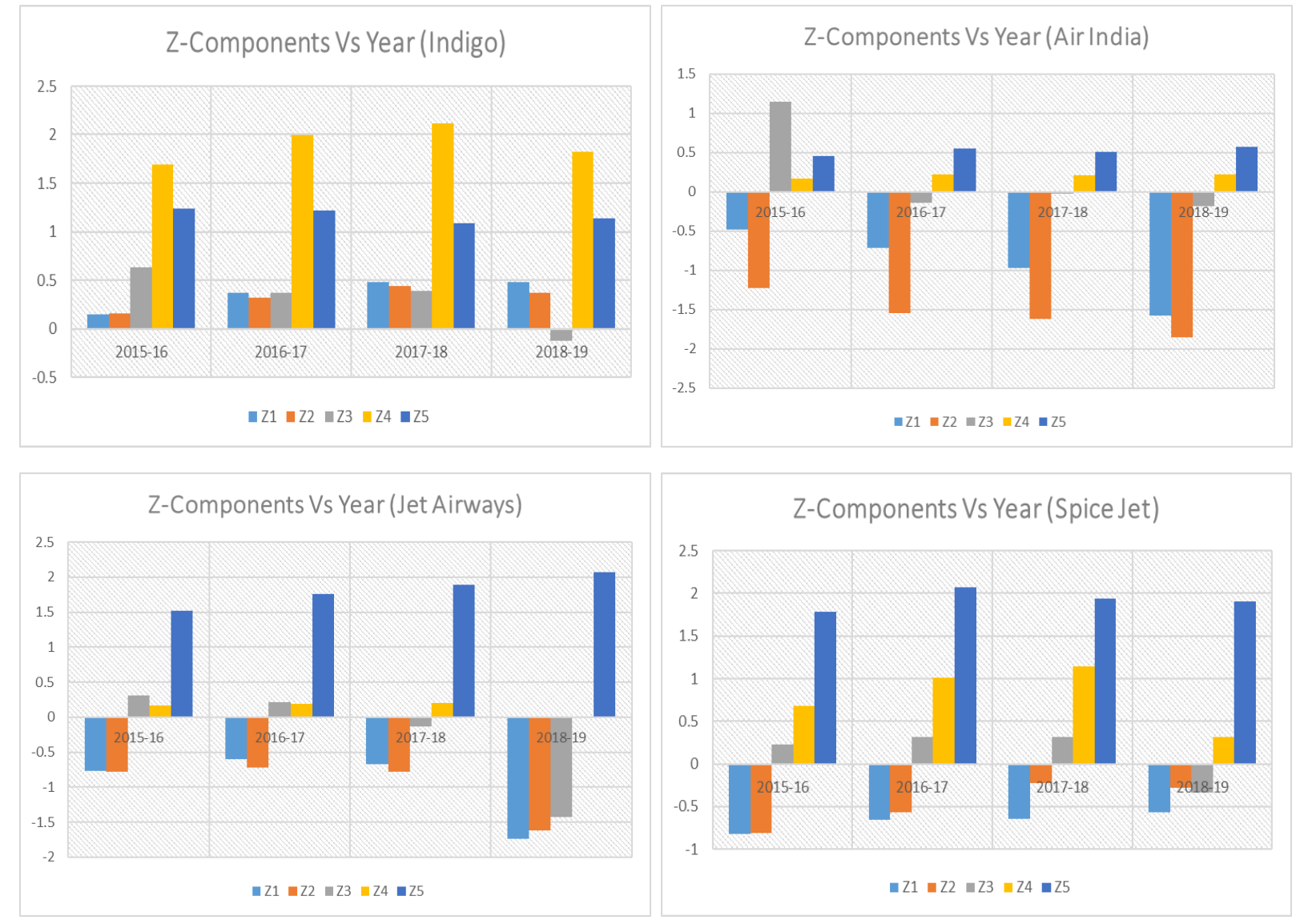

Figure 1. Graphical Representation of Z-Components of Different Aviation Companies 
Table 7. Z-Score Analysis

\begin{tabular}{|c|c|c|c|c|c|c|c|}
\hline \multicolumn{7}{|c|}{ Altman's Z-score for Indian Aviation Sector Companies as of March 31 } \\
\hline Company & Year(FY) & $\mathbf{Z 1}$ & $\mathbf{Z 2}$ & $\mathbf{Z 3}$ & $\mathbf{Z 4}$ & $\mathbf{Z 5}$ & Z-Score \\
\hline Indigo & $2015-16$ & 0.148849979 & 0.158496844 & 0.634294692 & 1.687984278 & 1.239708994 & 3.869334786 \\
\hline & $2016-17$ & 0.367798415 & 0.314587393 & 0.365807119 & 1.994902027 & 1.221618837 & 4.264713791 \\
\hline & $2017-18$ & 0.483226512 & 0.443466133 & 0.393512108 & 2.118104594 & 1.089524563 & 4.52783391 \\
\hline & $2018-19$ & 0.484600814 & 0.36704448 & -0.126981379 & 1.821768327 & 1.138648336 & 3.685080578 \\
\hline SpiceJet & $2015-16$ & -0.819964548 & -0.805716572 & 0.226286065 & 0.684985391 & 1.787354226 & 1.072944562 \\
\hline & $2016-17$ & -0.65276959 & -0.567894431 & 0.311496065 & 1.015896741 & 2.072072169 & 2.178800953 \\
\hline & $2017-18$ & -0.643952496 & -0.228280728 & 0.31639745 & 1.144717022 & 1.940543678 & 2.529424927 \\
\hline \multirow{2}{*}{ Jet Airways } & $2018-19$ & -0.56334444 & -0.277407272 & -0.338743696 & 0.313808737 & 1.903166006 & 1.037479334 \\
\hline & $2015-16$ & -0.762745463 & -0.774620621 & 0.314379021 & 0.165687091 & 1.524377243 & 0.467077272 \\
\hline & $2016-17$ & -0.602772639 & -0.71930143 & 0.210432058 & 0.18488923 & 1.761530347 & 0.834777565 \\
\hline & $2017-18$ & -0.667426934 & -0.783770858 & -0.138260251 & 0.206489229 & 1.891973734 & 0.50900492 \\
\hline & $2018-19$ & -1.742313932 & -1.61361631 & -1.428533405 & 0.008044528 & 2.07476004 & -2.701659079 \\
\hline Air India & $2015-16$ & -0.479059514 & -1.22693949 & 1.148069557 & 0.169165092 & 0.452274106 & 0.063509751 \\
\hline & $2016-17$ & -0.716003049 & -1.550039143 & -0.136508738 & 0.223767992 & 0.548655802 & -1.630127136 \\
\hline & $2017-18$ & -0.967083826 & -1.617940106 & -0.026594178 & 0.208593571 & 0.503618212 & -1.899406328 \\
\hline & $2018-19$ & -1.574944909 & -1.858974786 & -0.182786476 & 0.224627079 & 0.567673416 & -2.824405675 \\
\hline
\end{tabular}

Source: Author's Calculation. * Jet Airways data is taken on standalone basis for the year 2018-19

Graphical Representation of Z-Components of Different Aviation Companies is presented in Figure 1.

Graphical representation of Z-Score Analysis is presented in Figure 2.

Graphical representation of Z-Score Vs Years (2016-2019) is presented in Figure 3.

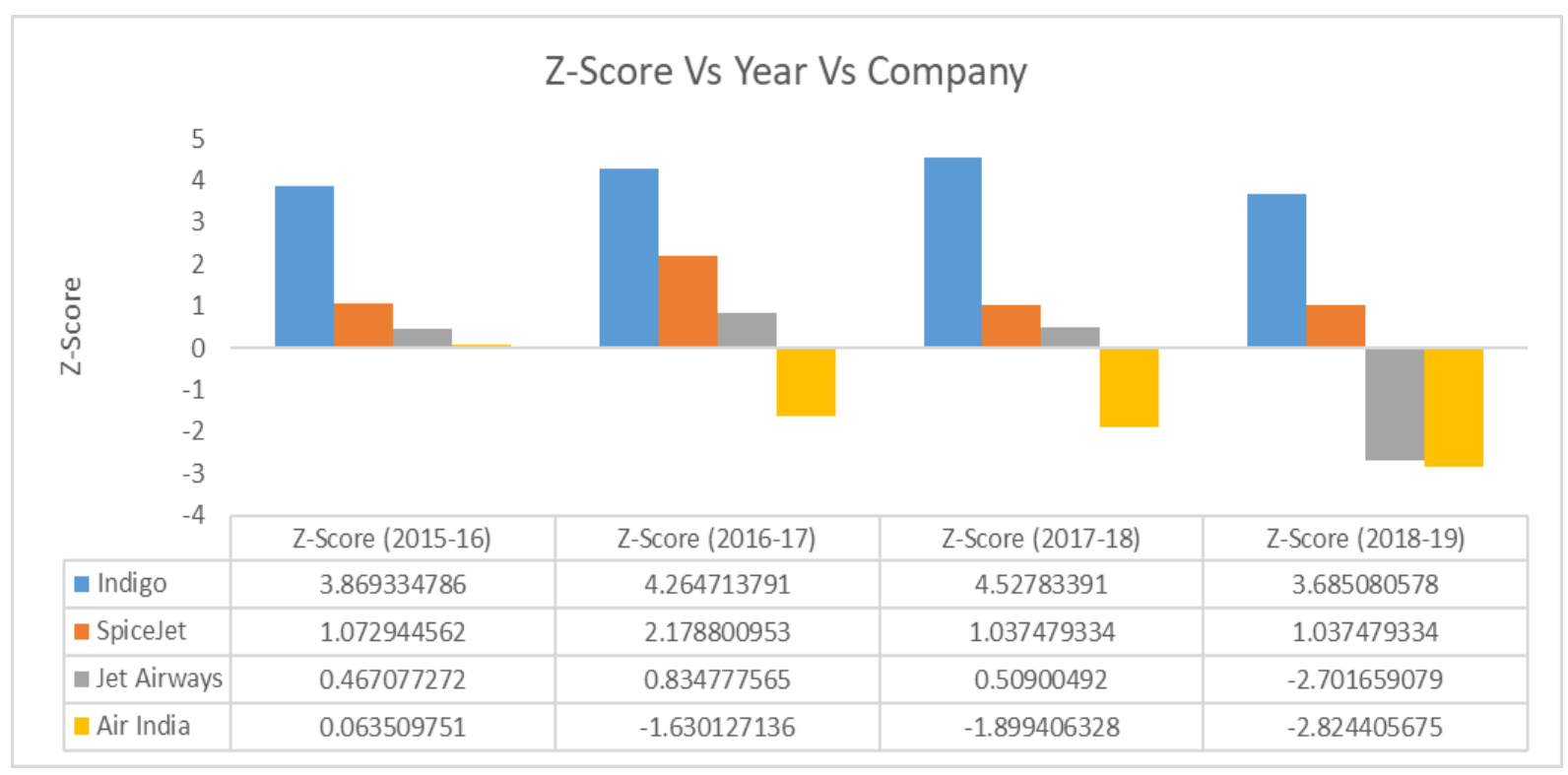

Figure 2. Graphical representation of Z-Score Analysis 


\section{Z-Score Vs Year}

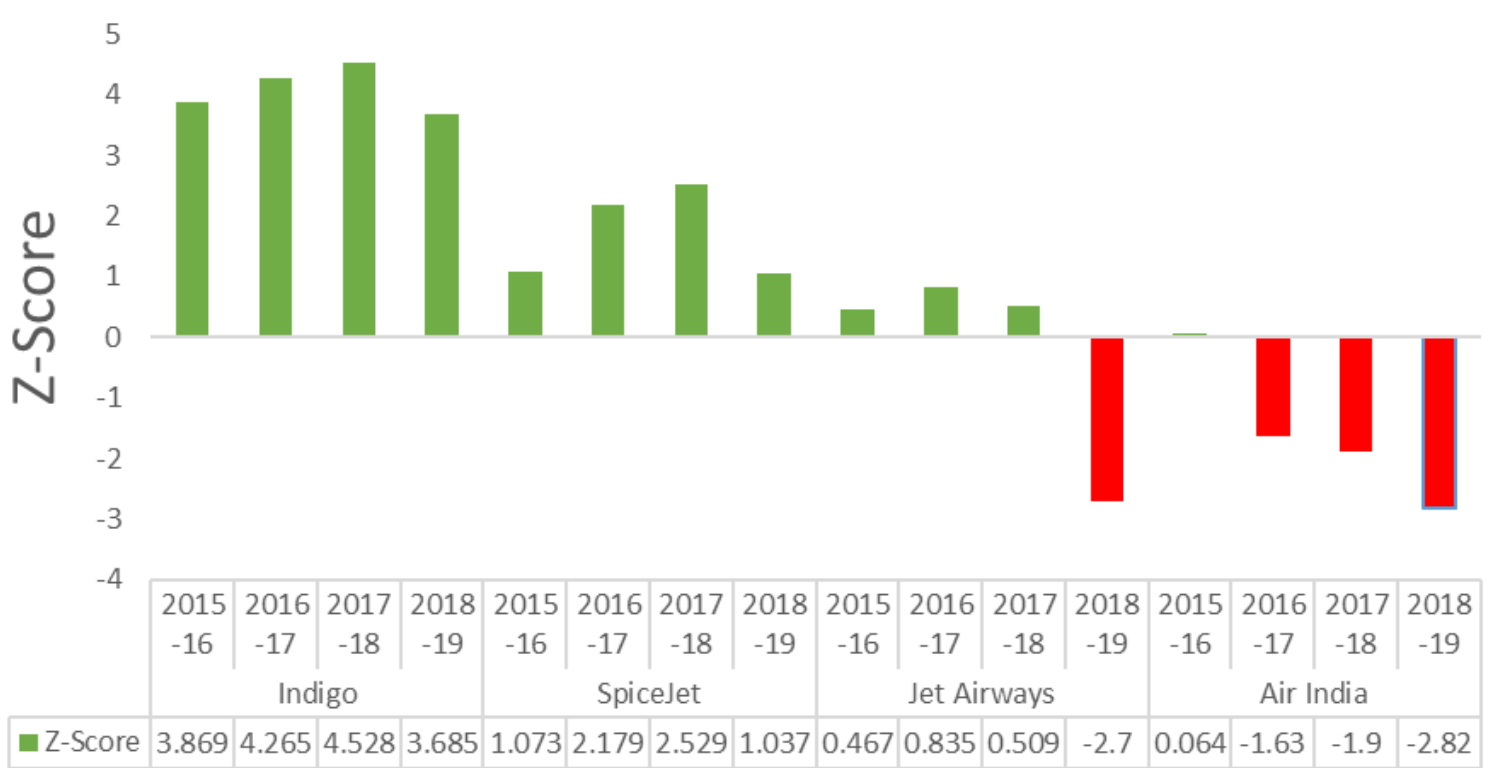

Figure 3. Graphical representation of Z-Score Vs Years (2016-2019)

Table 8. P-Score Analysis

\begin{tabular}{|c|c|c|c|c|c|c|}
\hline Indigo & Year & P1 & P2 & P3 & P4 & P5 \\
\hline & $2015-16$ & -2.454 & -0.56 & -1.218 & -0.196 & -0.369 \\
\hline & $2016-17$ & -2.418 & -1.112 & -2.84 & -0.276 & -0.215 \\
\hline & $2017-18$ & -2.157 & -1.567 & -5.655 & -0.334 & -0.316 \\
\hline & $2018-19$ & -2.254 & -1.297 & -5.604 & -0.316 & 0.08 \\
\hline Spice Jet & Year & P1 & P2 & P3 & P4 & P5 \\
\hline & $2015-16$ & -3.538 & 2.848 & 1.655 & -0.044 & -0.091 \\
\hline & $2016-17$ & -4.102 & 2.007 & 1.039 & -0.047 & -0.108 \\
\hline & $2017-18$ & -3.842 & 0.807 & 0.084 & -0.0435 & -0.117 \\
\hline & $2018-19$ & -3.768 & 0.98 & 0.618 & -0.052 & 0.128 \\
\hline & Year & $\mathbf{P 1}$ & $\mathbf{P 2}$ & $\mathbf{P 3}$ & $\mathbf{P 4}$ & P5 \\
\hline & $2015-16$ & -3.018 & 2.738 & 1.687 & -0.184 & -0.226 \\
\hline & $2016-17$ & -3.487 & 2.543 & 1.765 & -0.156 & -0.151 \\
\hline & $2017-18$ & -3.746 & 2.711 & 2.641 & -0.062 & 0.099 \\
\hline & $2018-19$ & -4.108 & 5.705 & 3.238 & -0.028 & 1.03 \\
\hline & Year & P1 & $\mathbf{P 2}$ & $\mathbf{P 3}$ & $\mathbf{P 4}$ & $\mathbf{P 5}$ \\
\hline & $2015-16$ & -0.895 & 4.338 & 0.898 & -0.049 & 0.417 \\
\hline & $2016-17$ & -1.086 & 5.48 & 1.011 & -0.051 & 0.443 \\
\hline & $2017-18$ & -0.997 & 5.72 & 1.128 & -0.047 & 0.448 \\
\hline & $2018-19$ & -1.123 & 6.572 & 1.872 & -0.007 & 0.584 \\
\hline
\end{tabular}

If we make analysis of the above indicators in further detail, we have to check one by one strategies and policies adopted by these companies. Indigo right from beginning which believed in Low-Cost Carrier concept started off very well. Company has their IPO in 2015 where they raised funds through issue of equity shares. Company adopted the model where they started to own the aircrafts rather than taking it on lease basis. No doubt huge money was blocked in Fixed Assets; Companies Balance Sheet became very strong. Since the major funding was done through Equity, there was no huge pressure of interest cost. Company gradually started filling the gap in the market 
which was created because of failure of Kingfisher Airlines. Started with just one aircraft in 2006, Indigo is the market leader. It kept same size of aircrafts Airbus A320 for years. Companies' sale and lease back policy has worked well. Better control on operating cost is the key to the success of Indigo. Less dependence on Debt funds is another reason. By 2010 Indigo was at number three just behind of Kingfisher and Jet Airways and now it is market leader in domestic business for years.

For any business ultimate object is to increase the wealth of shareholders. Indigo is the only company who has achieved this main object. If we observe for Spice Jet and for Jet Airways market prices of Equity shares are in now two digits. In fact, for Jet Airways trading is not taking place on day-to-day basis and company is in defaulters list of stock exchanges. As far as Air India is concern it is not listed on any stock exchange so there is no question of any market price. However, if we look at Government as Shareholder, Government has lost crores of rupees just to keep live Air India's business. In last 10 years Government has poured more than Rs.30, 000 Crore without any return, the only hope for the Government now to get rid of it by selling to other existing parties. Again, Government has postponed the last date for submission of bids from $31^{\text {st }}$ August, 2020 to $30^{\text {th }}$ October, 2020 with a hope to get a bidder.

\section{Discussion on $\mathrm{Z}$ score and $\mathrm{P}$ - Score is made at latter part of the paper}

Table 8 represents P-Score Analysis. Table 9 represents P-Scores of Indian Airlines. Figure 4 shows the P-Scores of Indian airline companies for different years (2016-2019). Figure 5 presents Year wise P-Components for different Indian Airlines Companies

Table 9. P-Scores of Indian Airlines

\begin{tabular}{|c|c|c|c|c|}
\hline P-Score & $\mathbf{2 0 1 5 - 1 6}$ & $\mathbf{2 0 1 6 - 1 7}$ & $\mathbf{2 0 1 7 - 1 8}$ & $\mathbf{2 0 1 8 - 1 9}$ \\
\hline Indigo & 0.0080000 & 0.0010000 & 0.0000465 & 0.0000834 \\
\hline Spice Jet & 0.6960000 & 0.2290000 & 0.0426000 & 0.1090000 \\
\hline $\begin{array}{c}\text { Jet } \\
\text { Airways }\end{array}$ & 0.7300000 & 0.6250000 & 0.8460000 & 0.9970000 \\
\hline Air India & 0.9910000 & 0.9960000 & 0.9980000 & 0.9990000 \\
\hline
\end{tabular}

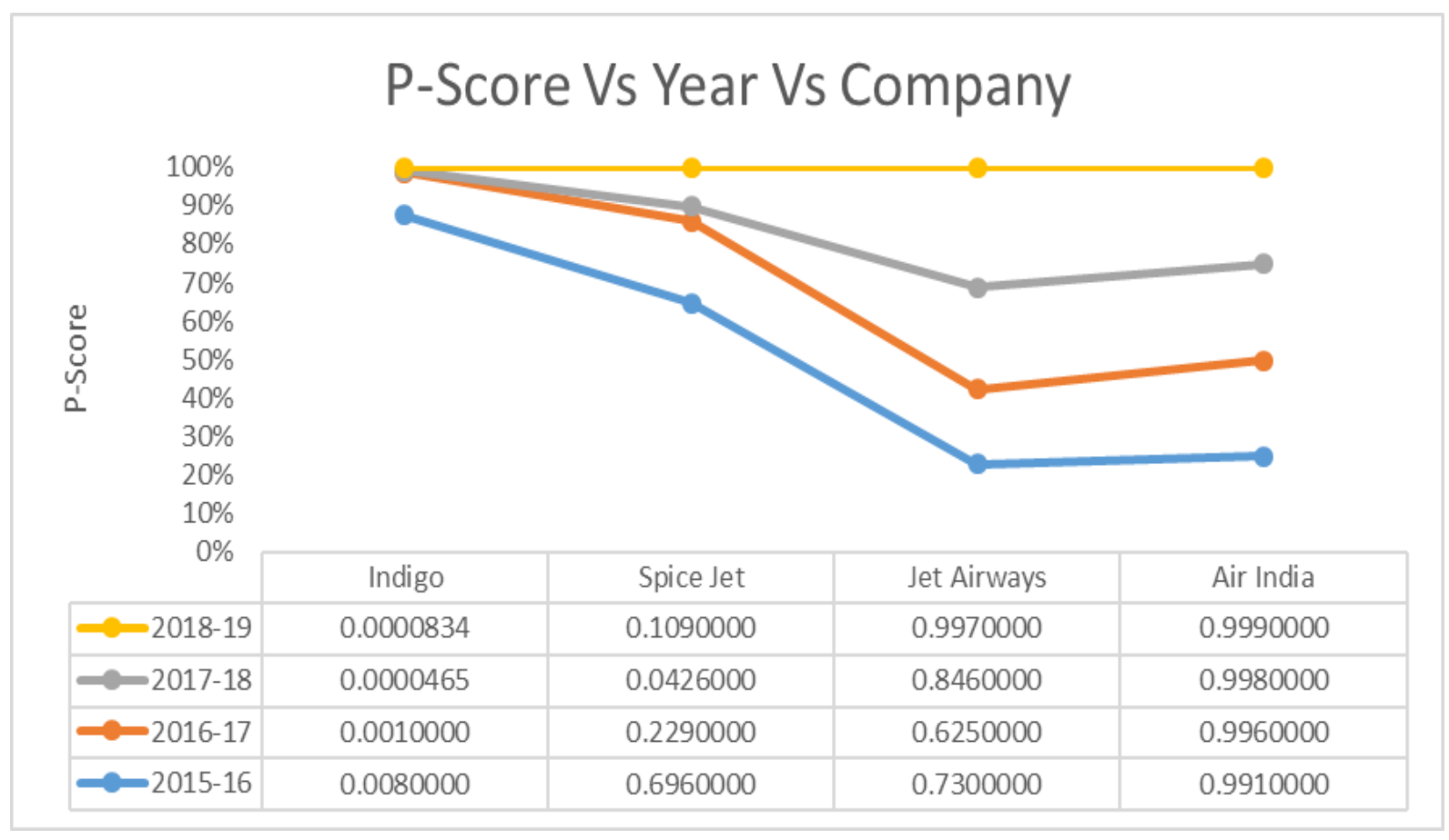

Figure 4. P-Scores of Indian airline companies for different years (2016-2019) 

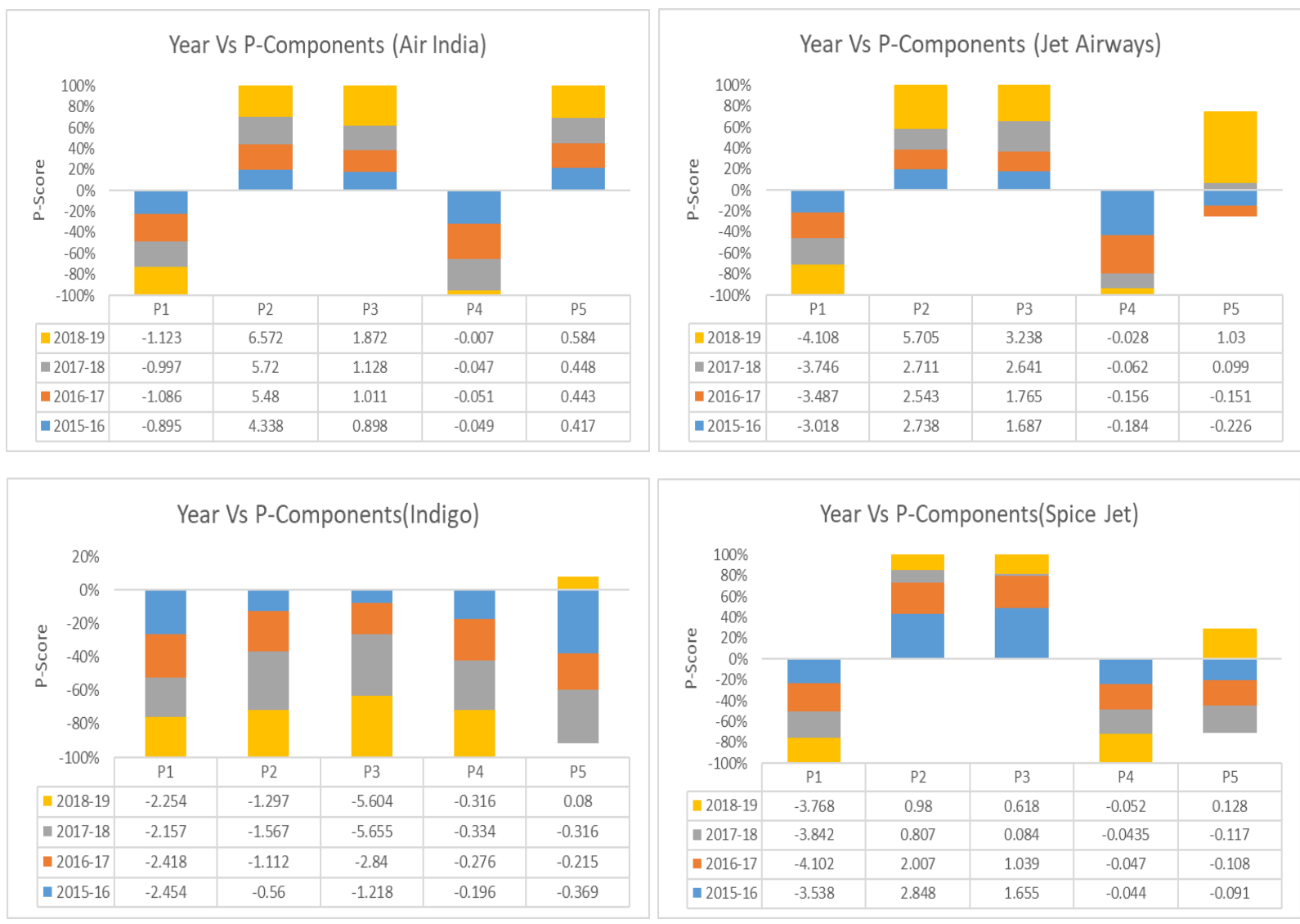

Figure 5. Year wise P-Components for different Indian Airlines Companies

\section{Financial Discussion by Using Z-Score Model}

\subsection{Indigo}

Indigo started as a low-cost carrier model. Used similar type of aircrafts and engines, short destinations, quick turnaround, point to point flights with low fares, Frequency of flights was reducing the fixed costs. Company was able to use cast experience of Rakesh Bhatia one of the founder member, in airlines industry. Indigo's Sale and Lease back strategy also worked for years. In 2005 they gave massive order of 100 fleets [13]. The sale and lease back policy removing the pressure on Balance sheet and it was becoming sounder on year-on-year basis. Company gone for IPO in 2015 which was very successful and after that company became market leader in the domestic market. The increasing middle-class population helped Indigo to reach that position. The disciplined approach of management has helped them to show a decent score of operating profits right from beginning when other competitors were struggling to show even average performance. $\mathrm{Z}$ score and P Score both are indicating financial soundness of Indigo.

Company has kept its borrowings within limits. It has kept a proper balance between Finance Leased and
Operating Leased aircrafts. In 2017 Indigo shifted its stance by ordering ATR flights which were different from A320 aircrafts what they were using. ATR aircrafts were requiring high skill pilots with higher salaries, during the same period there were lot many changes at management level, Aditya Ghosh, President after working for more than 10 years resigned. New management people are not specialist in LCC model. The dispute between two Promoters also has impacted on its business, not on day-to-day basis but at management level [14].

In last bid for Air India, Indigo also had applied showing clear signs of shifting from just LCC to international carrier. Immediate intention may be just to increase the network and gradually a long haul LCC. It has ordered A321 neo aircrafts for its international flights particularly to Europe. However, to grab the market of Jet Airways on its failure, Indigo has lost its discipline. They have lost due to Punctuality was the strength of Indigo was not maintained. Increased network at domestic level has broken the time table.

Covid 19 has changed the fate of Airlines industry in India as well as across the globe. However, in India at present Indigo is the only one who can survive in this situation because of its strong Balance Sheet. Company has taken so many steps to reduce its day-to-day cost from Rs.40 Crore per day to Rs. 30 Crore per day. Company has 
already planned to raise around Rs.4,000 crore through Qualified Institutional Placement (QIP) now only time will tell how company is going to manage in coming couple of years [15].

\subsection{Spice Jet}

Spice Jet is the only competitor to Indigo at present. After total failure of Jet Airways, market share of Spice Jet has increased to $15 \%$. Even though both Spice Jet and indigo started almost at the same time, Spice Jet got lot of turbulence in the beginning itself on management side and financial resources. Whereas for Indigo it was a smooth and steady take off. Number of aircrafts, number of flights, number of destinations in India and in abroad, Indigo is having number than Spice Jet. Banning of use of Boing 747 Max has also impacted on Spice Jet performance. Company has taken number of aircrafts from Jet Airways on lease basis. However, the fact remains is the only LCC airlines at present which can compete with Indigo is Spice Jet. Spice Jet is not financially very strong. There are debts in the Balance sheet right from beginning. Company is in losses right from beginning. Important plus point Spice Jet is having is its Promoter Director, Ajay Singh who is a very aggressive person and takes decisions according to the situation very fast. Covid 19 has impacted a lot on Spice Jet. It is difficult for it if it is not able to get around Rs. 2000 to Rs. 2500 crore immediately. Considering current position of the Balance sheet it is difficult for Spice Jet to get any external funding.

However, in this changed pandemic situation, Spice Jet has aggressively increased its cargo business significantly. Even though the aircrafts are taken on wet lease basis it will help the company for its survival. However, both Z Score and $\mathrm{P}$ score are not very encouraging for Spice Jet and if it is not getting any fresh funding it will be difficult for the company to again stabilize itself as close competitor of Indigo [16].

\subsection{Jet Airways}

Jet Airways once a leading Full-Service Carrier and market leader in India in domestic as well as in International front was not able to understand the threat from Low-Cost Carriers who started their operations in and around 2005 -2006. Jet Airways was not able to retain its corporate clients and at the same time was not able to handle the pressure created by LCC. Acquiring Air Sahara at 500 USD for cash in 2006 was a blunder. Jet Lite new name given to Air Sahara never succeeded and ultimately company had to write it off from its Balance Sheet.

At operational front Jet was not very professional and disciplined. Borrowings in the Balance Sheet were going up on year-on-year basis. Increasing crude oil prices in the international markets and at the same time weakening of rupee impacted a lot on Jet. It was impossible for Jet to survive where the LCC had started capturing the market.

On Financial front also Jet failed. RPK was always below CPK which increased the burden on the Balance sheet. High Debt and high finance cost were dragging Jet always in red. Company had not taken any strategic investor right from beginning and Management style of Mr. Naresh Goyal was not able to get any financer at the end. $\mathrm{Z}$ score and $\mathrm{P}$ - Score are clearly indicating financial distress of Jet Airways

\subsection{Air India}

Government has put Air India foe sale and in the last attempt it failed to attract any investor. Now Government has made second attempt and last date of submission of bid is 31st August, 2020. This time Government has made so many changes in the offer comparing to last attempt. Already Government of India has pumped in more than Rs.30, 000 crore as bailout package out of taxpayer's money and at present Air India flights are taking off only because of Government financial support [17].

For failure of Air India there are number of reasons. The aircrafts owned by it are wide body aircraft which are not required at domestic level. Air India's international business is in huge losses where they are not able to recover even cost per flight. Strategy of Air India to own the aircraft has ended with huge more than Rs. 60,000 crore loan in the Balance Sheet. In the year 2018-19 Air India achieved a total income of around Rs. 29,000 Crore with a loss of Rs.7200 Crore, loss from discontinued operations of Rs.1,500 crore with a total loss of Rs. 8700 crore. Lack of professionalism is another reason. For example, all other airlines, employees per aircraft are hardly 100 whereas for Air India the same ratio is 130 per aircraft. There is almost 4000 excess staff. Excess salary has increased the losses year on year basis. Huge Debts and huge Finance cost has made Air India unattractive for the buyers.

\subsection{Financial Discussion by using $\mathbf{P}$ - Score Model}

P - Model is another statistical model introduced by Pilaraski particularly to check the bankruptcy position of airlines Companies.

Apart from Indigo, all remaining Companies are having negative Reserves \& Surplus. Because of very high debt, Debt Equity ratio is in negative, High Fuel cost and Repairs and Maintenance cost is impacting on Operating Profits. For Air India employee cost is also impacting negatively. Companies barring Indigo don't have sufficient funds to repay the debts. All this position is indicated through P- Score of all these companies except Indigo. Scores are low only for Indigo whereas all remaining three companies score is high indicating bankruptcy position [18]. 


\section{Conclusions}

Airlines industry in India is right now on ventilator and the only company which has capacity to survive on its own is Indigo i.e., Inter globe Aviation Limited. Companies' strategy to own aircrafts rather than taking it on lease basis is working in such critical situation. Sale and Lease Back transactions will give scope to the company to generate fresh funds which are absolutely required at this stage where operations have gone down by almost by 80 to $85 \%$. Company is planning to raise funds by further issue of shares. Cost cutting is another measure company has taken and said that expenses per day have brought down from Rs. 40 crore per day to Rs. 30 crore per day. Company has recently reduced its work force by $10 \%$ which was around 27,000.Spice jet another Low-cost carrier in India is in financial problems and Auditors of the Company have raised concern about the Going Concern of this company. Considering financial position of the company there is less scope to get funds from the market. Company has to rely on any Government package.

Air India is on sale and Government has given $31^{\text {st }}$ August, 2020 as last date for submission of the bids. Company is in bad financial position with huge losses. Recently Boeing has discontinued supplying spare parts to Air India due to non-payment of earlier dues. The fate of Air India is now only depending on sale of its business to any professionally run airlines company like Tata's who shown interest in buying Air India. Jet Airways has already has stopped its operations and at least as of today there is no any hope of change in this situation and gradually this company will be liquidated.

\section{Result of the Study}

Overall conclusion is that to run airlines business absolute professionalism is required. Strong Balance Sheet is must which will have ability to raise funds at any point of time. Being LCC model is used, only option available is to control fixed costs, provide more quality service to the customers through punctuality and better on board services so as to attract more and more customers and create more cash generation. To focus more on other alternatives such as cargo business, for Indigo the sale and lease back policy has worked well and has helped to generate and keep more cash in the Balance sheet which is very useful in a panic situation. For Spicejet things have gone wrong right from beginning with the wrong capital structure and limitations to generate sufficient cash, For Jet Airways wrong acquisitions and failure or ignorance to understand impact of entry of LCC carriers brought to this situation and for Air India lack of efficiency in management and high fixed costs are the main reasons with less focus on domestic business.

\section{Abbreviations}

NSE, National Stock Exchange; EBIT, Earnings before Interest \& Tax; BSE, Bombay Stock Exchange

\section{REFERENCES}

[1] Anjum, S. (2012). Business bankruptcy prediction models: A significant study of the Altman's Z-score model. Available at SSRN 2128475.

[2] Beaver, W. H. (1966). Financial Ratios As Predictors of Failure. Journal of Accounting Research, 4, 71. https://doi.org/10.2307/2490171

[3] Bhatt, S. N. (2012). Capital structure and turnaround strategies using altman's Z-score models. Asian Journal of Research in Business Economics and Management, 2(7), 102-113.)

[4] Gowri, M., \& Sekar, M. (2014). Assessing the financial health of select automobile companies in India: A quantitative approach using the Z-Score multi-discriminant financial analysis model. Great Lakes Herald, March, 8(1), $32-45$.

[5] Gritta, R. D., Adrangi, B., Adams, B., \& Tatyanina, N. (2011, November). An update on airline financial condition and insolvency prospects using the Altman Z" score model. In Journal of the Transportation Research Forum (Vol. 47, No. 2).

[6] Kolte, A., Capasso, A., \& Rossi, M. (2017, September). Predicting financial distress of firms. A study on bankruptcy of Kingfisher Airlines. In 10th Annual Conference of the EuroMed Academy of Business (pp. 735-749).

[7] Kulkarni, S. (2018). Analysis of Z Score For BSE Listed Airline Companies In India. PARIDNYA-The MIBM Research Journal, 6(1), 24-29.

[8] Machek, O. (2014). Long-term predictive ability of bankruptcy models in the Czech Republic: evidence from 2007-2012. Central European Business Review, 3(2), 14-17.

[9] Pandey, S. L. D., \& Rathore, G. S. (2013). An Analysis of Bankruptcy in Indian Aviation Infrastructure Firms. The Indian Journal of Commerce, 66(3), 238-252.

[10] Pardeshi, B., \& Thorat, H. (2015). Evaluating the Financial Health of Central Public Sector Enterprises in India through Z Score Model. In Twelfth AIMS International Conference on Management, 2015.

[11] Pradhan, R. (2014). Z score estimation for Indian banking sector. International Journal of Trade, Economics and Finance, 5(6), 516.

[12] Rajasekar, T., Ashraf, S., \& Deo, M. (2014). An empirical enquiry on the financial distress of Navratna Companies in India. Journal of accounting and finance, 14(3), 100.

[13] Safiuddin, S. K. (2017). Prediction of Insolvency-A Study of Select Companies in Indian Aviation Industry. 
International Research Journal of Management Science \& Technology, 8(10), 304-309.

[14] Safiuddin, S. K. (2019). IMPACT OF LIQUIDITY, PROFITABILITY AND EFFICIENCY PERFORMANCE ON Z-SCORE OF SELECT INDIAN AVIATION COMPANIES. Advance and Innovative Research, 158.

[15] SHOME, S., \& VERMA, S. (2020). Financial Distress in Indian Aviation Industry: Investigation Using Bankruptcy Prediction Models. Eurasian Journal of Business and Economics, 13(25), 91-109.

[16] Tyagi, V. (2014). A Study to Measures the Financial Health of Selected Firms with Special Reference to Indian Logistic Industry: An Application of Altman's Z Score. Industrial Engineering Letters, 4(4), 43-52.
[17] Tyagi, V., \& Datta, M. (2017). Bankruptcy Potential of Indian Aviation Industry: An Analysis of Selected Firms. Research Bulletin, 42(4), 38-49.

[18] Wang, Y., \& Campbell, M. (2010). Do Bankruptcy Models Really Have Predictive Ability? Evidence using China Publicly Listed Companies. International Management Review, 6(2).

[19] Anindya Ardiansari, Siti Ridloah, Irene Rini Demi Pangestuti and Pipit Indrayani (2021) The Influence of Intellectual Capital on the Company's Financial Performance and Market Value. Universal Journal of Accounting and Finance, 9 (2), pp. 217-225. DOI: 10.13189/ujaf.2021.090211. 